\title{
A Case of Mucosa-Associated Lymphoid Tissue Lymphoma in Nasopharynx and Thyroid Gland
}

\author{
Woo Sung Park, Seok Hwa Ko, Byung Joon Yoo, and Jae Ho Chung \\ Department of Otorhinolaryngology-Head and Neck Surgery, Hanyang University College of Medicine, Seoul, Korea
}

\author{
비인강 및 갑상선에 발생한 점막연관 림프조직 림프종 1예 \\ 박우성 · 고석화 · 유병준 · 정재호 \\ 한양대학교 의과대학 이비인후-두경부외과학교실
}

Received July 26, 2016

Revised September 27, 2016

Accepted October 17, 2016

Address for correspondence

Jae Ho Chung, MD

Department of Otorhinolaryngology-

Head and Neck Surgery,

Hanyang University

College of Medicine,

222-1 Wangsimni-ro, Seongdong-gu,

Seoul 04763, Korea

Tel $+82-31-560-2368$

Fax $+82-31-566-4884$

E-mail jaeho.chung.md@gmail.com
Mucosa associated lymphoid tissue (MALT) lymphoma refers to a type of marginal zone lymphomas, which represent a group of non-Hodgkin lymphomas originated from B lymphocytes of marginal zone. They are classified as extranodal MALT type (MALT lymphoma), splenic marginal zone B-cell lymphoma and nodal marginal zone B-cell lymphoma according to clinical and therapeutic implications of the tumor. MALT lymphoma is the most common type of marginal zone lymphoma, and about $5-8 \%$ of all B-cell lymphomas are diagnosed as MALT lymphoma. MALT lymphomas are usually found in the gastrointestinal tract, mostly in the stomach associated with $\mathrm{H}$ pylori infection; the non-gastric MALT lymphoma can also be found in the salivary gland, lung, head and neck, ocular adnexa, skin, thyroid, or breast. However, the involvement of nasal cavity and nasopharynx is rare. Based on our recent experience and a review of related literature, we report a case of MALT lymphoma that occurred in the nasopharynx and thyroid gland, which were treated with localized radiotherapy.

Korean J Otorhinolaryngol-Head Neck Surg 2017;60(11):579-83

Key Words Mucosa-associated lymphoid tissue lymphoma - Nasopharynx ·

Thyroid gland.

\section{서 론}

점막 연관성 림프조직(mucosa associated lymphoid tissue, MALT) 림프종은 저악성도의 B 세포 기원의 비호지킨 림프 종으로서, 변연부 림프종(marginal zone) 중 가장 흔한 타입 이다. ${ }^{1,2)}$ 주로 림프절 이외의 점막연관성 림프조직(MALT)에 발생하는 것으로 알려져 있다. ${ }^{3)}$ 일반적으로 증상발현이 느리 고 장시간 동안 발생부 점막에 국한된 병변으로 존재하는 경 향이 있어 '가림프종(pseudo-lymphoma)'으로 알려져 있기도 하였으나, 현재는 국소 재발 또는 원격 전이, 고악성도 B세포

This is an Open Access article distributed under the terms of the Creative Commons Attribution Non-Commercial License (http://creativecommons.org/licenses/by-nc/4.0) which permits unrestricted non-commercial use, distribution, and reproduction in any medium, provided the original work is properly cited.
림프종으로의 변형 가능성을 가진 림프종으로 인식되고 있다. 특이하게도 점막연관 림프조직이 정상적으로 분포하는 말 단 회장이나 편도 등이 아닌, 주로 위장, 소장 등의 위장관계 점막에 발생하는 것으로 알려져 있으며, 폐, 갑상선, 타액선, 눈물샘 등에서도 발생하는 것으로 보고되어 있다. ${ }^{4)}$

저자들이 조사한 국내 문헌상 비강에 발생한 MALT 림프 종은 현재까지 1 예가 보고되었으며, ${ }^{5}$ 비인강에 발생한 경우 는 현재까지 보고된 바가 없었다. 일반적으로 장시간 동안 국 한된 점막의 병변으로 존재하며, 증상의 발현이 없고 진단의 어려움이 있어 드물게 보고되고 있는 것으로 사료된다.

저자들은 양측 청력 저하 및 이충만감을 주소로 내원한 환 자에서 비인강 내 종괴 소견을 발견하고, 조직검사 및 영상의 학적 검사를 통해 최종적으로 비인강 및 갑상선을 침범한 
MALT 림프종으로 진단된 예를 경험하였기에 문헌 고찰과 함께 보고하는 바이다.

\section{증 례}

55세 여자 환자가 양측 청력 저하 및 이충만감을 주소로 내 원하였다. 증상은 내원 1달 전부터 시작되었으며, 이비인후과 1 차 의원에서 삼출성 중이염으로 소견이 확인되었으며, 내시 경 검사상 비인강에 이관 입구를 막고 있는 양상의 종괴 소견 이 관찰되어 본원 이비인후과에 진료 의뢰되었다. 과거력 및 가족력상 기저질환으로 고혈압이 있었던 점 외 특이사항은 없 었으며, 이학적 검사상 양측 고막 내 액체 저류 소견이 관찰되 었다. 비내시경 검사에서 양측 로젠뮬러와(rosenmuller fossa) 및 이관융기(torus tubarius)를 전위시켜 이관(Eustachian tube)을 폐쇄하고 있는 양상의 비인두 종물이 관찰되었으며, 후비루 소견이 동반되어 있었다(Fig. 1). 고실도에서 양측 모 두 type $\mathrm{B}$ 소견이, 순음 청력 검사에서 우측 $42 \mathrm{~dB}$, 좌측 38 $\mathrm{dB}$ 의 기도 청력 역치가 확인되었으며, 우측은 $15 \mathrm{~dB}$, 좌측은 $5 \mathrm{~dB}$ 의 기도골도차가 관찰되었다. 경부 조영증강 전산화단
층촬영에서 비인강의 전반적인 부종 소견 및 갑상선 좌엽의 결절이 관찰되었다(Fig. 2). 1주일간 항생제를 포함한 보존적 치료를 시행하였으나 증상의 호전이 보이지 않아, 양측 고막 절개술 및 환기관 삽입술을 시행하였고, 비인강 종물에 대해 비인강 암 또는 림프종 등의 악성 종양 가능성을 염두에 두 고 내시경하 조직검사를 시행하였다. 면역조직화학검사를 포 함한 병리 조직검사상 림프구성 세포들로 이루어진 림프종으 로, 배중심(germinal center) 및 외투층(mantle zone)이 관찰 되는 점막연관 림프조직이 확인되었으며, 주변 변연부(marginal zone)의 확장소견이 관찰되었다(Fig. 3). CD79a, CD20, Bcl-2 염색에 양성반응을 보였으며, CD5, CD10, Cyclin D1 염색에 음성 반응을 보여, 다른 타입의 림프종일 가능성이 배제되었으며, 점막연관 림프조직 림프종으로 진단할 수 있 었다. 전신전이 확인을 위해 시행한 양전자 단층 촬영상 양 측 비인강 및 좌측 갑상선에 섭취 증가 소견이 확인되었으며 (Fig. 4), 갑상선 결절의 악성 여부를 확인하기 위해 세침 조 직검사를 추가로 시행하였다. 갑상선 결절에 대한 조직검사 에서도 여포세포 사이로 침윤한 림프구성 세포들을 확인할 수 있었으며, 면역 염색상 점막연관 림프조직 림프종으로 진
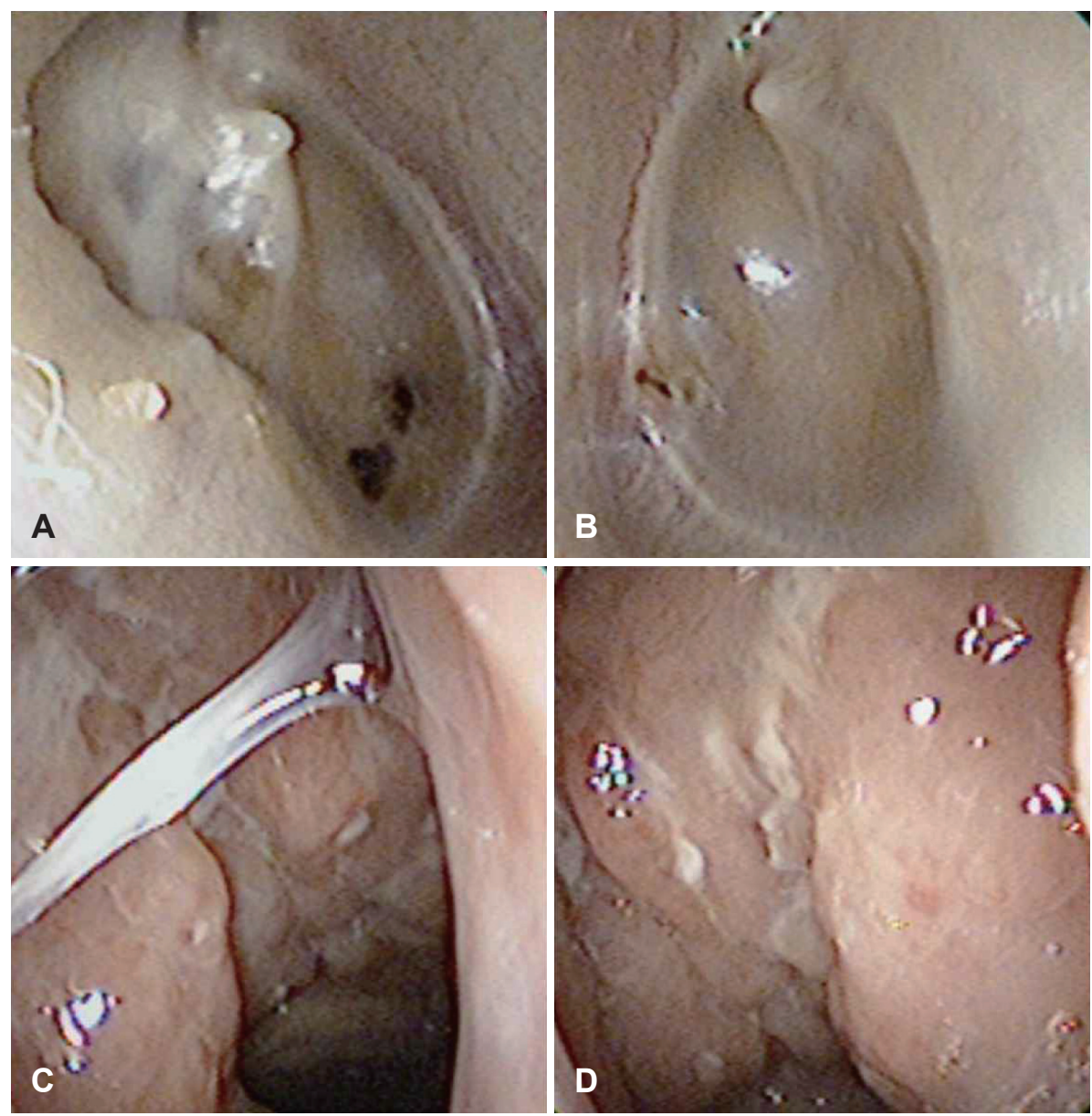

Fig. 1. Endoscopic images for both tympanic membranes (A and B), nasopharynx through right nasal cavity $(\mathrm{C})$, and nasopharynx through left nasal cavity (D) at first visit. 
단되었다. 따라서 비인강 및 림프절외 장기인 갑상선을 침범 한 Ahn Arbor 분류상 병기 IV에 해당하는 위장관 외 점막 연관 림프조직 림프종으로 진단하였으며, 비인강 및 갑상선
부위에 17회에 걸쳐 $3000 \mathrm{cGy}$ 의 방사선 치료를 시행하였다.

치료 1 개월 후 시행한 경부 단층 촬영에서 갑상선의 병변은 소실되었으며, 비인강의 부종도 호전되었다. 또한 초진 시 관
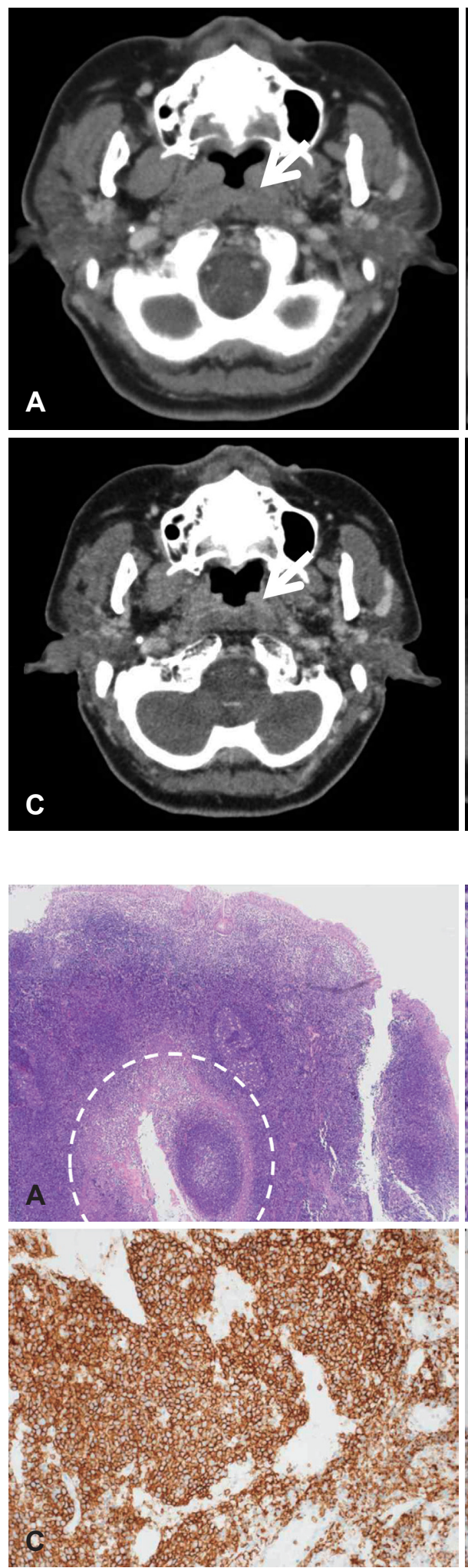
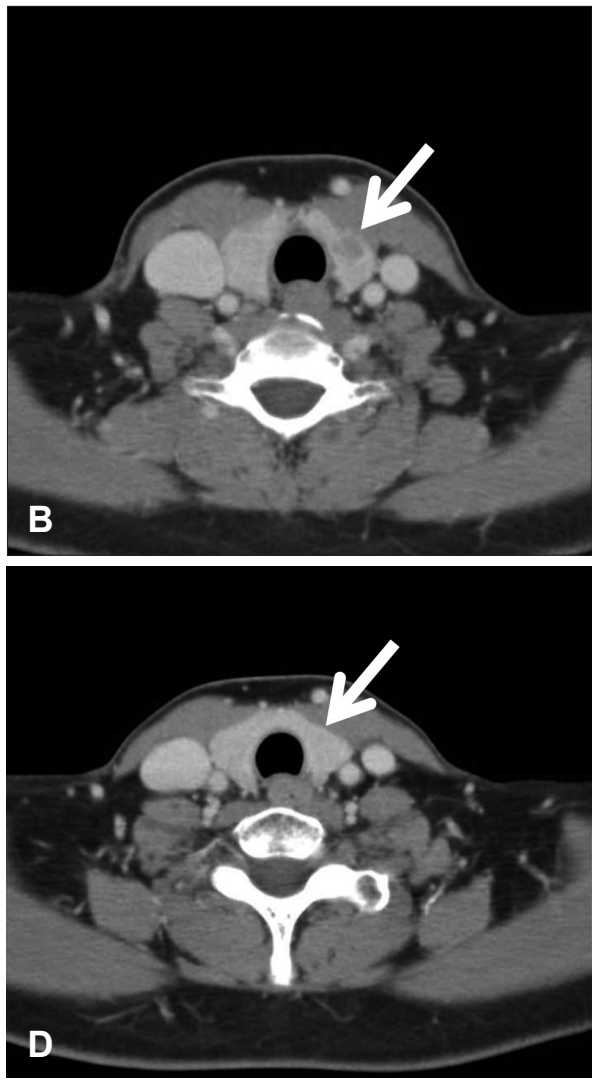

Fig. 2. Neck CT with contrast enhance scan showing bilaterally enlarged nasopharyngeal mucosa (A, arrow), and nodule in left thyroid gland $(B$, arrow). And post-radiotherapy CT image of same area ( $\mathrm{C}$ and $\mathrm{D}$, arrow).
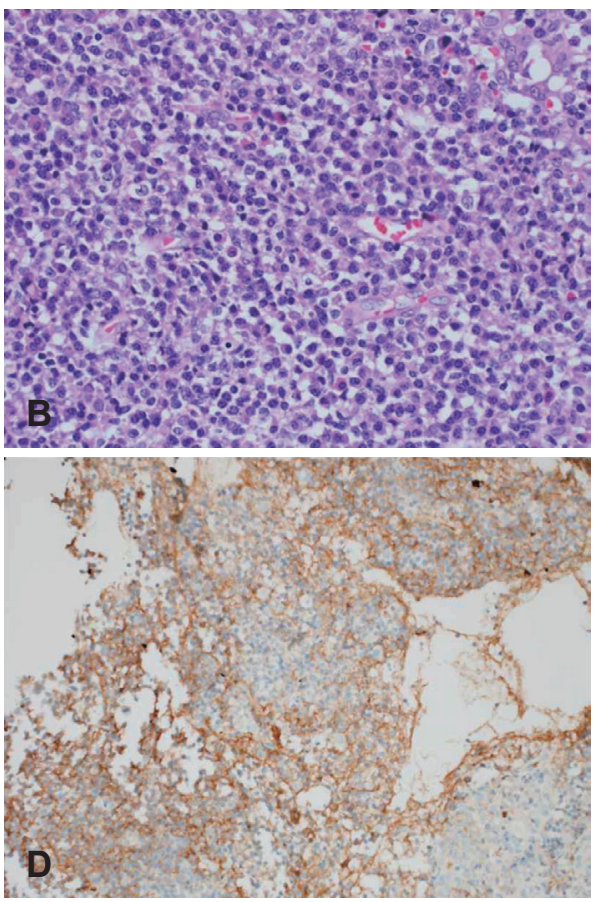

Fig. 3. Pathologic findings. MALT was shown in nasopharynx tissue, with germinal center surrounded by expansile marginal zone (in dotted circle, $H \& E, \times 100)(A)$, and atypical plasma cells with abundant cytoplasm and hyperchromatic nuclei were shown in marginal zone $(\mathrm{H} \& \mathrm{E}$, $\times 1000$ ) (B). Immunohistochemistric findings shown positive in CD20 stain (C), and lgM stain (D). MALT: mucosa associated lymphoid tissue. 

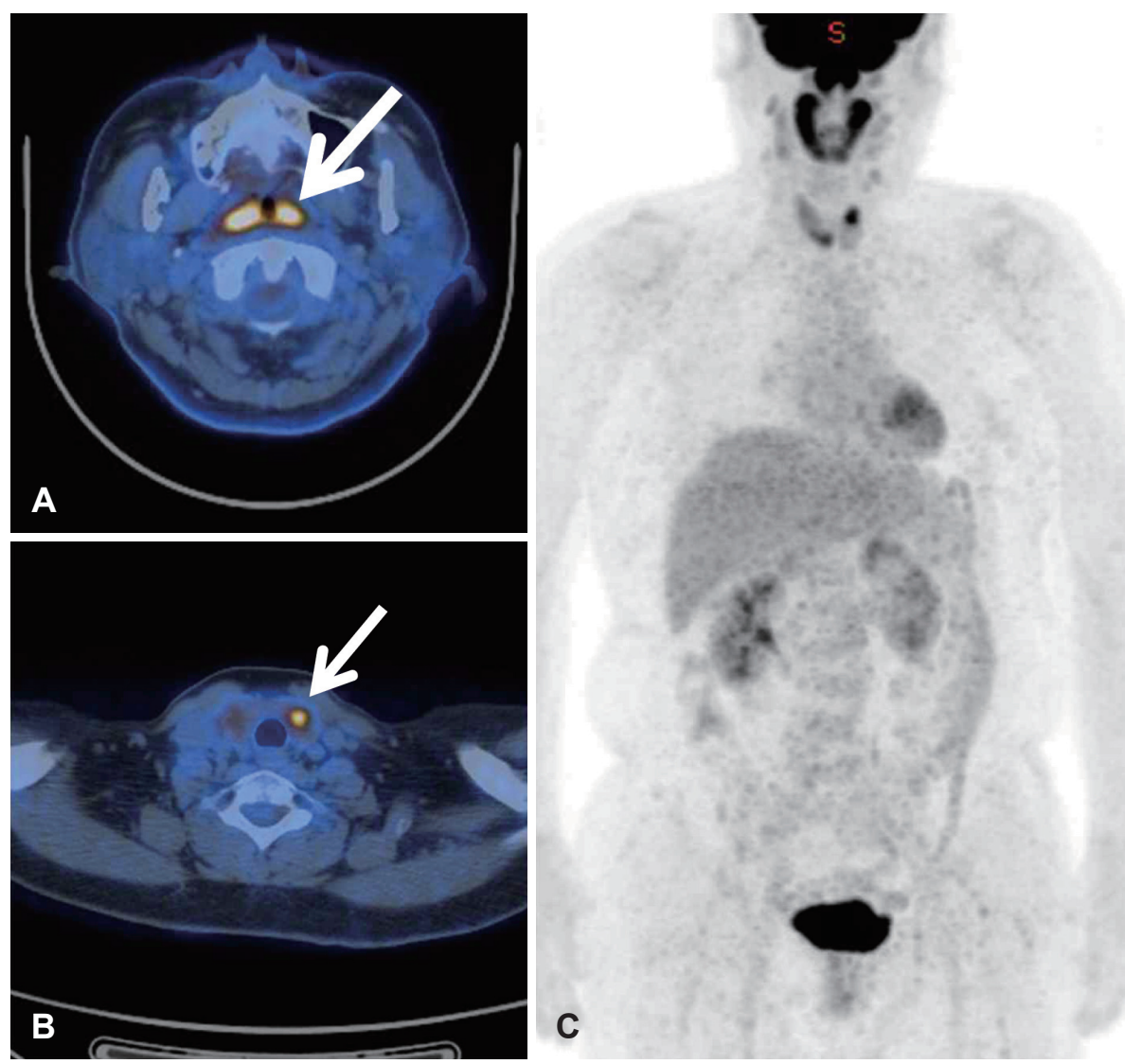

Fig. 4. $P E T C T$. Diffuse swelling with increased FDG uptake in bilateral nasopharynx (A, arrow) and left thyroid gland ( $B$, arrow). Several mild hypermetabolic lesions in both neck level II and left level III suspected as reactive lymph nodes, and no other demonstrable hypermetabolic lesions (C).

찰되던 중이 삼출물도 소실되어 난청, 이충만감도 호전되었 다. 환자는 방사선 치료 종료 후 5 개월이 지난 현재까지 재발 및 합병증 없이 경과 관찰 중이다.

\section{고 찰}

두경부 영역에서의 악성 림프종은 이 부위에 호발하는 비 상피성 암 중에서 가장 흔하며, 6,7$)$ 국내 보고에 의하면 전체 악 성 종양의 약 $3 \%$ 를 차지한다. ${ }^{8)}$ 악성 림프종은 조직병리학적 으로 크게 호지킨병과 비호지킨 림프종으로 나눌 수 있으며, 비강 또는 비인강에 발생하는 경우 주로 비호지킨 림프종의 T 세포형이 발생하는 것으로 알려져 있다. MALT 림프종의 경우 1980년대 Isaacson과 Wright'에 의해 그 개념이 체계화되어, 현재는 비호지킨성 림프종 중 $\mathrm{B}$ 세포형 림프종으로 분류되 어 있으며, 주로 위장관계 점막에서 H. pylori 감염에 의한 지 속적인 면역 반응으로 $\mathrm{B}$ 세포의 증식에 의해 발생하는 종양 으로 알려져 있다. 위 이외에도 침샘, 피부, 안구 또는 결막, 폐, 갑상선, 상기도, 유방 또는 간에서도 발생할 수 있으며, ${ }^{10)}$ 위 이 외의 장기에서 발생하는 MALT 림프종은 각 장기간 조직학적 으로 유사성을 보이고, 임상 경과나 양상이 위장관계 MALT 림프종과 비슷한 것으로 보고되어 있다. ${ }^{11}$
대부분의 MALT 림프종은 진행이 느린 양상을 보이며,2) 다른 림프종에 비해 예후가 좋다. 10년 생존율 및 10년 무병 생존율이 각각 79 87\%, 57 76\% 정도로 보고되고, 위 또는 두경부 영역의 MALT 림프종의 경우 무병 생존기간이 더 길 게 나타나는 것으로 알려져 있다. ${ }^{12)}$ 장시간 동안 발생부 점막 에 국한된 병변으로만 존재하는 경향이 있어 일반적으로 증 상발현이 느리며, 비강에 발생한 경우 일반적으로 부비동염 의 증상과 비슷한 양상을 보이거나 눈물관의 폐쇄를 초래하 여 유루증을 유발할 수 있고, ${ }^{5}$ 갑상선에 발생한 경우 갑상선 기능의 저하를 보이거나, 종괴의 크기로 인한 압박증세나 연하 곤란, 호흡곤란 등의 증세를 보인다. ${ }^{13)}$ 비강 및 갑상선에 단일 병변으로 발생한 MALT 림프종의 경우 문헌상 드물게 보고 되고 있지만,5) 비인강 및 갑상선에 MALT 림프종이 발생한 경 우는 보고된 바 없다.

진단은 전산화단층촬영, 초음파 검사, 자기공명영상촬영, 동위원소 촬영 등이 이용되고 있으며, 위장관계의 경우 H. pylori와의 연관이 깊어 요소호기 검사(urea breath test) 등이 보조적으로 이용되기도 한다. 조직학적 진단을 위해 세침흡 인 세포검사 또는 수술적 조직검사가 시행되며, 조직검사상 일 반적으로 중심세포형 세포(centrocyte-like cell), 형질세포 및 비정형 림프구가 림프절 외 상피조직을 침범한 양상의 조직 
학적 소견을 보인다. 이러한 림프상피 병변은 일반적인 염증 반응에서도 비슷하게 관찰될 수 있어 MALT 림프종을 감별 하고, 진단하기 위해서는 면역조직화학적 검사가 필수적이다. 면역조직화학 염색상 B 세포 표지자인 CD19, CD20, CD22, $\mathrm{IgM}, \mathrm{bcl}-2$ 등에서 양성을 나타내며, IgD, CD5, CD10, Cyclin $\mathrm{D} 1$ 그리고 $\mathrm{CD} 23$ 에서 음성을 나타내는 것으로 알려져 있다. 본 증례에서도 $\mathrm{CD} 79 \mathrm{a}, \mathrm{CD} 20, \mathrm{Bcl}-2$ 염색에 양성 반응을, CD5, $\mathrm{CD} 10, \mathrm{Cyclin} \mathrm{D1}$ 염색에 음성 반응을 보였으며, 주변 변연부 의 확장을 보이는 점막연관 림프조직(MALT)을 확인하여, MALT 림프종에 합당한 소견을 확인할 수 있었다(Fig. 3).

병기의 경우 주로 Ahn Arbor 분류에 의해 I, II 단계의 조 기암과 III, IV 단계의 진행암으로 분류하게 된다. I, II 단계 에 해당하는 단발성으로 존재하는 국한된 MALT 림프종의 경우 방사선 치료를 일차적으로 사용할 수 있으며, 조사선량 은 2400 3000 cGy 정도가 권고된다. ${ }^{14)}$ 수술적 제거의 경우 진단적 목적으로 시행하는 것이 일반적이며, 폐와 같이 방사 선 치료를 하기 힘든 부위에 한해서는 치료적인 목적으로 시 행되기도 한다. 추가적인 항암화학치료의 경우 생존율이나 무병 생존율에 별다른 영향을 끼치지 못하는 것으로 알려져 있으며, 방사선 치료를 할 수 없는 환자의 경우 선택적으로 시 행되기도 한다. 다발성 전이를 포함한 III, IV 단계의 진행암 의 경우 현재까지는 정립되어 있는 치료법이 없으며, CD20에 대한 단일클론 항체인 Rituximab 등의 약제를 이용한 면역치 료 등, 소포성 림프종의 치료와 비슷한 방법으로 치료한다. ${ }^{15)}$ 본 증례의 경우 1 곳의 림프절 외 장기(갑상선) 및 비인강을 침 범하였기에 Ahn Arbor 분류의 IV기에 해당한다. 하지만 두 곳의 종물이 침습적이지 않고 동일한 방사선 치료 영역에 해 당하여 방사선 치료만 시행하였으며 치료 후 완전히 관해되 었다.

이충만감을 주소로 외래에 내원한 본 환자의 증례에서, 저 자들은 영상학적 검사를 통해 비인강의 종괴 소견을 확인하 여, 악성 종양 의심하에 조직검사를 시행하였다. 이후 양전자 단층촬영상 함께 악성이 의심된 갑상선 결절에 대한 추가적 인 조직검사상, 두 군데의 병변 모두에서 MALT 림프종을 확인한 경우였다. 일반적인 이비인후과 진료 환경에서 이와 같이 이충만감과 같은 평범한 이과적 증상을 주소로 내원한
환자에서 비인강암 등의 비인강 병변을 확인하기 위한 이학 적 검사나 비내시경 검사를 시행하여야 함은 과거에도 많은 강조가 있어 왔다. 이러한 경우 아데노이드 비대증 등의 양성 질환뿐 아니라, 비인강암, 림프종의 가능성까지 염두에 두어 야 한다는 점을 다시 한 번 환기시켜준 증례라고 여겨진다.

\section{REFERENCES}

1) A clinical evaluation of the International Lymphoma Study Group classification of non-Hodgkin's lymphoma. The Non-Hodgkin's Lymphoma Classification Project. Blood 1997;89(11):3909-18.

2) Olszewski AJ, Castillo JJ. Survival of patients with marginal zone lymphoma: analysis of the surveillance, epidemiology, and end results database. Cancer 2013;119(3):629-38.

3) Bacon CM, Du MQ, Dogan A. Mucosa-associated lymphoid tissue (MALT) lymphoma: a practical guide for pathologists. J Clin Pathol 2007;60(4):361-72.

4) Isaacson PG. Update on MALT lymphomas. Best Pract Res Clin Haematol 2005;18(1):57-68

5) Shin MS, Lim SC. Mucosa-associated lymphoid tissue lymphoma arising from the nasal mucosa: a case report and review of the literature. Korean J Otolaryngol 2006;49(12):1227-30.

6) Choi CY, Jo YK, Lee BH, Lee YW, Lee KD, Yu TH. Analysis of treatment in the patient with non-Hodgkin's lymphoma of the head and neck. Korean J Otolaryngol 1997;40(12):1820-5.

7) Freeman C, Berg JW, Cutler SJ. Occurrence and prognosis of extranodal lymphomas. Cancer 1972;29(1):252-60.

8) Kim HT, Im YH, Suh CI, Park YS, Kang WK, Heo DS, et al. Malignant lymphomas in Korea. J Korean Cancer Assoc 1992;24(1):92-101.

9) Isaacson P, Wright DH. Malignant lymphoma of mucosa-associated lymphoid tissue. A distinctive type of B-cell lymphoma. Cancer 1983; 52(8):1410-6.

10) Zucca E, Conconi A, Pedrinis E, Cortelazzo S, Motta T, Gospodarowicz MK, et al. Nongastric marginal zone B-cell lymphoma of mucosaassociated lymphoid tissue. Blood 2003;101(7):2489-95.

11) Harris NL, Isaacson PG. What are the criteria for distinguishing MALT from non-MALT lymphoma at extranodal sites? Am J Clin Pathol 1999;111(1 Suppl 1):S126-32.

12) Zucca E, Bertoni $F$. The spectrum of MALT lymphoma at different sites: biological and therapeutic relevance. Blood 2016;127(17): 2082-92.

13) Wozniak R, Beckwith L, Ratech H, Surks MI. Maltoma of the thyroid in a man with Hashimoto's thyroiditis. J Clin Endocrinol Metab 1999;84(4):1206-9.

14) National Comprehensive Cancer Network. Non-Hodgkin's lymphomas version 4.2014. [cited 2016 Sep 15]. Available from: https://www. nccn.org/about/nhl.pdf.

15) Zucca E, Conconi A, Laszlo D, López-Guillermo A, Bouabdallah $\mathrm{R}$, Coiffier B, et al. Addition of rituximab to chlorambucil produces superior event-free survival in the treatment of patients with extranodal marginal-zone B-cell lymphoma: 5-year analysis of the IELSG-19 randomized study. J Clin Oncol 2013;31(5):565-72. 